\title{
PENILAIAN KINERJA PEGAWAI DI PEMERINTAH KOTA YOGYAKARTA
}

Lena Satlita, Yanuardi dan Marita Ahdiyana ${ }^{1}$

\begin{abstract}
This research aims to describe the performance appraisal of Yogyakarta government employees as well as enabling and inhibiting factors in the assessment of employee performance in Yogyakarta government. This qualitative descriptive research shows there are two performance appraisals in the government of Yogyakarta namely Employee Performance Assessment and Job Performance Assessment government employee. Employee Performance Assessment carried out 2 times a year, in June and December and the performance appraisal only once a year. Assessment methods used in employee performance assessment is a method 360 degrees. Constraints in the evaluation of employee performance assessment is at fault understanding of the guidelines for the implementation of performance appraisal, lack of clear job description in job analysis make it difficult for employees to put it in the assessment and the absence of stylists executive staffing in evaluation of employee performance and timing issues assessment by the employer because constrained by other activity.
\end{abstract}

Key Words: Performance Appraisal, Assessment Indicators, Government Employees of Yogyakarta.

\begin{abstract}
ABSTRAK
Penelitian ini membahas mengenai penilaian kinerja pegawai di Pemerintah Kota Yogyakarta beserta faktor pendukung dan penghambat dalam penilaian kinerja pegawai Pemerintah Kota Yogyakarta. Penelitian ini menggunakan pendekatan kualitatif dan menunjukan ada dua penilaian kinerja yaitu Penilaian Kinerja Pegawai (PKP) dan Penilaian Prestasi Kerja PNS (SKP). Penilaian kinerja pegawai dilakukan 2(dua) kali dalam setahun, pada bulan Juni dan Desember. Penilaian kinerja dilakukan dengan metode 360 derajat. Faktor penghambat dalam evaluasi penilaian kinerja karyawan yaitu kurangnya deskripsi pekerjaan yang jelas dalam analisis pekerjaan membuat sulit bagi karyawan untuk memasukkannya dalam penilaian dan tidak adanya staf dalam mengevaluasi kinerja karyawan dan penilai terkendala oleh aktivitas lainnya.
\end{abstract}

Kata Kunci: Penilaian Kinerja, Indikator Penilaian, PNS Kota Yogyakarta.

1 Dosen, Fakultas Ilmu Sosial, Universitas Negeri Yogyakarta, email: satlita@yahoo.com, yanuardi@uny.ac.d, marita_ahdyana@uny.ac.id 


\section{PENDAHULUAN}

Kualitas sumber daya manusia (SDM) Pegawai Negeri Sipil (PNS) di instansi pemerintah merupakan salah satu faktor untuk meningkatkan produktivitas kinerja suatu organisasi atau organisasi pemerintah. Oleh karena itu diperlukan SDM yang mempunyai profesionalisme dan kompetensi yang tinggi untuk dapat mendukung peningkatan kinerja PNS. Tetapi seberapa besar kontribusi tersebut, masih harus diukur. Penilaian kinerja/ prestasi kerja merupakan cara untuk mengukur kontribusi yang diberikan. Dipandang dari segi manfaatnya bagi organisasi, penilaian prestasi kerja di suatu organisasi adalah program yang sangat penting dilaksanakan dalam rangka mengetahui pencapaian sasaran kerja setiap individu karyawan.

Proses penilaian kinerja menyebabkan sebagian besar karyawan merasa tidak nyaman dan tidak puas karena penilaian kinerja pada beberapa posisi tidak mampu mengukur secara objektif, ada keterbatasan kemampuan kognitif penilai maupun belum adanya kesepakatan tentang standar kinerja yang baik. Permasalahan empirik dalam penilaian kinerja di instansi pemerintah menunjukkan proses penilaian pelaksanaan pekerjaan PNS cenderung terjebak kedalam proses formalitas. DP3PNS telah kehilangan arti dan makna substantif, tidak berkait langsung dengan apa yang telah dikerjakan PNS, DP3-PNS secara substantif tidak dapat digunakan sebagai penilaian dan pengukuran besar produktivitas dan kontribusi PNS terhadap organisasi. Selain itu pengukuran dan penilaian prestasi kerja oleh atasan langsung sebagai pejabat penilai sering hanya sekedar menilai, tidak didasarkan pada target goal, sehingga proses penilaian cenderung bias dan bersifat subyektif.

Pemerintah Kota (Pemkot) Yogyakarta merupakan salah satu pemerintah daerah di Indonesia yang dikenal berhasil dalam melaksanakan reformasi birokrasi. Pemkot Yogyakarta merumuskan delapan area perubahan yang menjadi tujuan reformasi birokrasi yang meliputi organisasi, tatalaksana, peraturan perundang-undangan, sumber daya manusia aparatur, pengawasan, akuntabilitas, pelayanan publik, serta mindset dan culture set aparatur. Area perubahan yang diharapkan pada sumber daya aparatur adalah SDM aparatur yang berintegritas, netral, kompeten, capable, profesional, berkinerja tinggi dan sejahtera. Berdasarkan hasil penelitian Lena Satlita, dkk yang berjudul Pelembagaan Reformasi Birokrasi di Pemkot Yogyakarta (2014: 43-45) dapat dilihat keberhasilan kegiatan penataan Sistem Manajemen SDM. Pemkot 
Yogyakarta menata pegawai berdasarkan kompetensi dan kualifikasi jabatan, menyusun SIMPEG yang di integrasikan ke SIM KOMPETENSI, membuat Sistem Aplikasi Pelayanan Pegawai untuk sarana mengetahui psikologi bagi pegawainya. Pemerintah kota juga menyusun analisis beban kerja di semua SKPD dan membuat regulasi, norma terhadap pelaksanaan analisis jabatan, penyusunan pola karier pegawai, penyusunan standar jabatan dan kegiatan evaluasi jabatan, kegiatan assessment individu berdasarkan kompetensi dan penerapan sistem penilaian kinerja individu.

Suatu hal yang menarik, penilaian prestasi kerja di Pemkot Yogyakarta juga dihubungkan dengan pemberian tambahan penghasilan, seperti tertera dalam Peraturan Walikota Yogyakarta No.43 tentang Pemberian Tambahan Penghasilan bagi Pemkot Yogyakarta, bahwasanya tambahan penghasilan yang diberikan secara bulanan kepada pegawai daerah di luar gaji/upah, tunjangan jabatan struktural, tunjangan jabatan fungsional umum, berdasarkan bobot jabatan, penilaian kinerja dan kedisisplinan.

Berdasar uraian di atas, penting kiranya untuk meneliti penilaian kinerja pegawai Pemerintah Kota Yogyakarta serta faktor pendukung dan penghambat dalam penilaian kinerja pegawai Pemerintah Kota Yogyakarta.

\section{METODE PENELITIAN}

Tipe penelitian ini adalah deskriptif kualitatif. Lokasi penelitian di Badan Kepegawaian Daerah Kota Yogyakarta. Unit analisis dalam penelitian ini adalah penilaian kinerja pegawai Pemerintah Kota Yogyakarta. Waktu penelitian mulai bulan Mei sampai dengan Agustus 2015.Teknik pengumpulan data dalam penelitian ini dilakukan melalui wawancara, observasi dan dokumentasi yang diperoleh dari berbagai peraturan terkait dengan penilaian kinerja/ prestasi kerja, buku-buku, foto, catatan,dan laporan-laporan kegiatan yang terkait dengan aktivitas yang telah dilakukan. Penentuan subyek penelitian dengan menggunakan teknik purposive. Narasumber dalam penelitian ini berasal dari pihak yang tahu betul dan terlibat dalam penilaian kinerja pegawai yaitu, Asisten Administrasi Umum Sekretariat Daerah Kota Yogyakarta, Kepala Bidang Pengembangan Sumber Daya Pegawai BKD, Kasubid Akuntabilitas Aparatur BKD dan Analis Kepegawaian Pertama.

Peneliti menggunakan teknik trianggulasi untuk menguji keabsahan data penelitian ini, yaitu teknik pemeriksaan keabsahan data dengan memanfaatkan sesuatu yang lain di luar 
tersebut. Berdasarkan PP No.46 Tahun 2011, DP3 yang banyak biasnya disempurnakan dengan Penilaian Prestasi Kerja PNS yang secara sistematik menggabungkan antara penilaian Sasaran Kerja Pegawai NegeriSipil (SKP) dengan penilaian perilaku kerja. Dengan mengingat adanya berbagai kelemahan dalam penilaian kinerja pegawai, maka Pemerintah Kota Yogyakarta dalam melakukan penilaian kinerja PNS menggunakan dua macam/jenis penilaian yaitu PKP dan SKP.

Dari Tabel 1 dapat dilihat bahwa semakin tinggi nilai yang diperoleh masing-masing pegawai, maka semakin baik sebutan yang diberikan oleh pegawai tersebut. Meskipun terdapat dua jenis penilaian pegawai, akan tetapi keduanya dilakukan tidak secara bersamaan sehingga tidak terjadi benturan. Penilaian SKP dilaksanakan dalam satu kali dalam satu tahun sedangkan untuk penilaian PKP dilaksanakan dua kali dalam satu tahun. Unsur atau aspek-aspek yang dinilai dalam SKP dan PKP terdapat satu dua persamaan, tetapi sesungguhnya keduanya berbeda. Penilaian SKP merupakan perubahan dari DP3, dan dibandingkan dengan DP3, SKP lebih rasional karena memiliki ukuran-ukuran yang jelas dan terdapat penilaian terhadap capaian tugas sehingga SKP obyektivitas lebih terjamin dibandingkan DP3 yang sangat subyektif.

SKP menggunakan unsur-unsur yang dinilai berdasarkan kontrak kinerja dan pengamatan sedangkan PKP hanya pengamatan saja. Pemerintah Kota Yogyakarta dalam melakukan penilaian kinerja pegawai dilaksanakan di unit SKPD masing-masing dan dalam 1 (satu) tahun dilaksanakan dua periode penilaian, periode penilaian I dilaksanakan pada bulan Juni, dan periode penilaian II dilaksanakan pada bulan Desember, penilaian akhir adalah gabungan dari penilaian periode I dan II yang dituangkan dalam blangko penilaian akhir Penilaian Kinerja Pegawai. Pejabat penilai wajib melaksanakan penilaian kinerja pegawai terhadap pegawai yang menjadi bawahannya.

\section{Penilaian Prestasi Kerja Pegawai}

Penilaian prestasi kerja merupakan suatu proses rangkaian manajemen kinerja yang berawal dari penyusunan Sasaran Kerja Pegawai (SKP), penetapan tolok ukur yang meliputi aspek kuantitas, kualitas, waktu, dan biaya dari setiap kegiatan tugas jabatan.

Landasan dari penilaian prestasi kerja pegawai negeri sipil ini adalah Peraturan Pemerintah Nomor 46 Tahun 2011 tentang Penilaian Prestasi Kerja 
PNS. Kemudian penilaian prestasi kerja

PNS dilakukan berdasarkan prinsip:

a. Objektif adalah penilaian terhadap pencapaian prestasi kerja sesuai dengan keadaan yang sebenarnya tanpa dipengaruhi oleh pandangan atau penilaian subjektif pribadi dari pejabat penilai.

b. Terukur adalah penilaian prestasi kerja yang dapat diukur secara kuantitatif dan kualitatif.

c. Akuntabel adalah seluruh hasil penilaian prestasi kerja harus dapat dipertanggungjawabkan kepada pejabat yang berwenang.

d. Partisipatif adalah seluruh proses penilaian prestasi kerja dengan melibatkan secara aktif antara pejabat penilai dengan PNS yang dinilai.

e. Transparan adalah seluruh proses dan hasil penilaian prestasi kerja bersifat terbuka dan tidak bersifat rahasia.

Pelaksanaan penilaian prestasi kerja pegawai Pemerintah Kota Yogyakarta tidak dipersiapkan secara khusus. Waktu penilaian dilakukan pada saat pegawai yang bersangkutan sudah selesai mengentri uraian dan target kinerja sesuai SKP yang telah ditanda tangani pada awal tahun (Bulan Januari), tempatnya di lingkup Pemkot Yogyakarta. Dan penilaian berakhir di akhir tahun (Bulan Desember). Dalam melaksanakan penilaian SKP dilakukan dengan cara membandingkan antara realisasi kerja dengan target yang telah ditetapkan.

Dalam melakukan penilaian dilakukan analisis terhadap hambatan pelaksanaan pekerjaan pegawai untuk mendapatkan umpan balik serta menyusun rekomendasi perbaikan dan menetapkan hasil penilaian pegawai Pemerintah Kota Yogyakarta.

Dengan mencermati gambar tersebut dapat diketahui bahwa terdapat dua aspek dalam penilaian kinerja yaitu sasaran kerja PNS dan perilaku kerja. Selain penilaian kinerja pegawai dan

\section{Gambar 2. Unsur penilaian prestasi kerja}

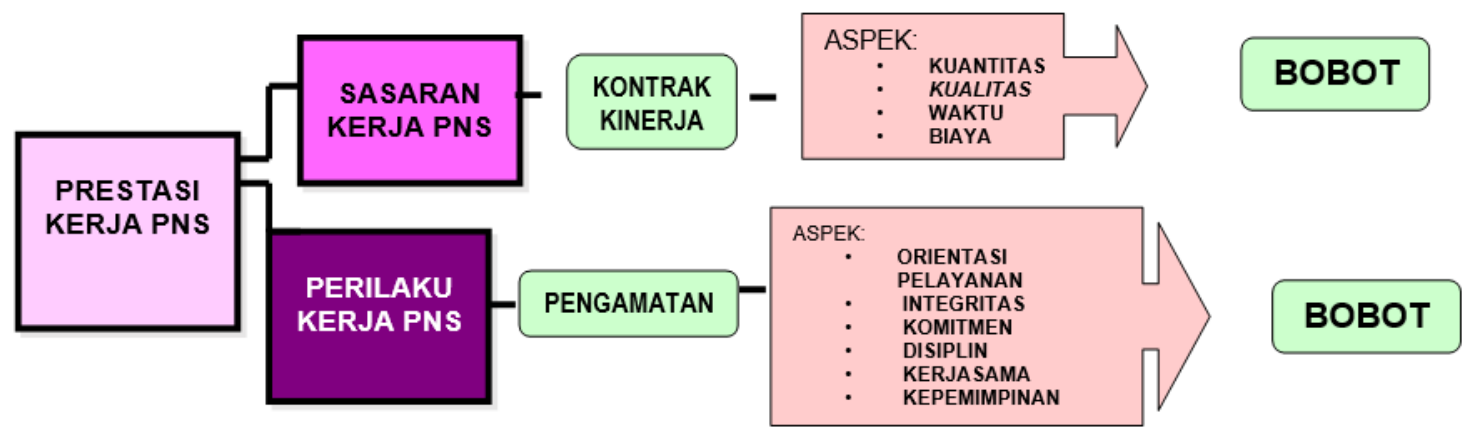


presatasi kerja pegawai, Pemerintah Kota

Yogyakarta melakukan penilaian tugas tambahan kepada PNS. PNS yang melakukan tugas tambahan dari atasannya akan mendapat penilaian tambahan dengan cara mencantumkan bukti surat keterangan.

Semakin sering pegawai melakukan tugas tambahan yang diberikan atasannya maka semakin besar nilai yang diperoleh pegawai tersebut. Dalam pelaksanaanya tidak jarang terjadi PNS yang pindah/mutasi dari instansi pemerintah yang satu ke instansi yang lain, jika terjadi hal seperti itu maka buku catatan penilaian perilaku kerja dikirimkan oleh pimpinan instansi lama kepada pimpinan instansi baru. Jika seorang PNS pindah unit organisasi tetapi masih tetap dalam instansi yang sama, maka hanya buku catatan penilaian perilaku kerja saja yang dikirimkan oleh pimpinan unit organisasi yang lama kepada pimpinan unit organisasi yang baru.

Berdasarkan penilaian yang terjadi selama ini hasil penilaian pegawai Pemerintah Kota Yogyakarta rata rata mendapatkan B dalam pencapaian target. Hal tersebut wajar karena untuk mencapai A tentu saja sulit karena manusia tidak ada yang sempurna. Dan hasil ini sudah benar-benar mencerminkan kualitasnya kinerja sesungguhnya karena terdapat instrumen yang menjamin keotentikan hasil penilaian.

Masih sering terjadi kendala dalam pelaksanaan penilaian SKP pada pemerintah kota Yogyakarta yaitu pada kesalahan pemahaman terhadap pedoman pelaksanaan penilaian prestasi kerja, seperti kesalahan dalam pengisian SKP yang seharusnya diisi dengan tugas pokok pegawai, namun oleh pegawai dituliskan tugas apa saja dilakukan yang bukan termasuk tugas pokok. Kendala Utama dalam penilaian Kinerja SKP yaitu:

1) Kurang jelasnya uraian tugas dalam dokumenan alisis jabatan menyulitkan pegawai menuangkannya dalam SKP (kegiatan tugas jabatan)

2) Muncul kesulitan dalam penyusunan SKP terutama terkait kegiatan tugas jabatan apas aja yang harus dituangkan dalam SKP dan yang menjadi tugas tambahan

3) Kesulitan dalam menentukan Target (kuantitas, kualitas, waktu, dan biaya) yang sesuai dengan standard atau tujuan organisasi

4) Belum ada Penata Pelaksana Kepegawaian di SKPD yang menangani SKP

5) Waktu, penilaian dari atasan karena terkendala dengan kesibukan lainnya. 
Pendampingan, bimbingan teknis dan workshop kepada seluruh pegawai di lingkup Pemerintah Kota Yogyakarta merupakan cara untuk mengatasi kendala-kendala dalam penilaian kinerja yang terjadi selama ini.

Realisasi kerja dengan target dari aspek kuantitas, kualitas, waktu dan/atau biaya dinilai dengan baik. Penilaian prestasi kerja dilakukan dengan cara menggabungkan penilaian SKP dengan penilaian perilaku kerja. Penilaian dilakukan oleh atasan PNS yang bersangkutan (pejabat penilai) dan divalidasi oleh atasan pejabat penilai. Pejabat penilai wajib melakukan penilaian prestasi kerja terhadap setiap PNS di lingkungan unit kerjanya. Pejabat pembina kepegawaian sebagai pejabat penilai dan/atau atasa pejabat penilai yang tertinggi di lingkungan unit kerja masing-masing.

Hasil penilaian kinerja pegawai dituangkan dalam Blangko Penilaian Kinerja Pegawai. Blangko penilaian kinerja pegawai ini disiapkan oleh Penatalaksana Kepegawaian. Penatalaksana kepegawaian akan menyampaikan kepada pejabat penilai maupun staf yang ditunjuk untuk menilai. Untuk menjamin keontetikan hasil penilaian maka terdapat tahapan verifikasi dokumen hasil pelaksanaan kinerja pegawai. Untuk tahap verifikasi ini maka terdapat blangko. Blangko ini berisi rincian bukti fisik dari masingmasing uraian tugas jabatan yang telah disusun sedari awal sesuai SOTK. Setelah blangko penilaian kinerja diisi oleh pejabat atau staf yang ditunjuk kemudian masing-masing unsur kinerja pegawai dipindahkan dalam Daftar Nilai Kinerja Pegawai yang jumlah rangkap 2 diberikan kepada instansi dan BKD.

\section{SIMPULAN}

Terdapat dua penilaian kinerja di Pemerintah Kota Yogyakarta yaitu Penilaian Kinerja Pegawai (PKP) dan Penilaian Prestasi Kerja PNS (SKP). Penilaian kinerja pegawai diatur pada Peraturan Walikota Yogyakarta Nomor 23 Tahun 23 Tahun 2007 tentang Penilaian Kinerja Pegawai. Sedangkan untuk penilaian prestasi kerja PNS diatur pada Peraturan Pemerintah Nomor 46 Tahun 2011 tentang Penilaian Prestasi Kerja PNS. Penilaian kinerja pegawai pada Penilaian Prestasi Kerja PNS meliputi dua yaitu Sasaran Kerja Pegawai (SKP) dan Perilaku Kerja. Penilaian Kinerja Pegawai dilaksanakan 2 kali dalam satu tahun yaitu pada bulan Juni dan Desember, tetapi penilaian prestasi kerja hanya satu tahun sekali. Metode penilaian yang digunakan pada PKP adalah metode 360 derajat. Hasil 
penilaian pegawai di Pemerintah Kota Yogyakarta dipandang sudah dapat mencerminkan kualitas kinerja pegawai yang sesungguhnya karena dalam pelaksanaan penilaian menggunakan instrumen yang menjamin keontetikan hasil penilaian.

Kendala dalam penilaian SKP yaitu pada kesalahan pemahaman terhadap pedoman pelaksanaan penilaian prestasi kerja, kurang jelasnya uraian tugas dalam dokumen analisis jabatan menyulitkan pegawai menuangkannya dalam SKP (kegiatan tugas jabatan, kesulitan dalam penyusunan SKP terutama terkait kegiatan tugas jabatan apa saja yang harus dituangkan dalam SKP dan yang menjadi tugast ambahan, kesulitan dalam menentukan target (kuantitas, kualitas, waktu, danbiaya) yang sesuai dengan standard atau tujuan organisasi, belum ada Penata Pelaksana Kepegawaian di SKPD yang menangani SKP dan masalah Waktu penilaian dari atasan karena terkendala dengan kesibukan lain.

Dalam rangka mengatasi berbagai kendala dalam penilaian kinerja di Pemerintah Kota Yogyakarta, maka terdapat beberapa rekomendasi sebagai berikut:

1. Untuk mengatasi kendala dalam pelaksanaan PP No 46 Tahun 2011, BKD Kota perlu melaksanakan Bimbingan teknis Penilaian Kinerja
(SKP) pada semua SKPD agar kesulitan dalam penyusunan SKP dan kesulitan menentukan Target sesuai dengan standard atau tujuan organisasi dapat teratasi.

2. Untuk pelaksanaan penilaian kinerja berdasarkan UU No 5 Tahun 2014 ASN sebaiknya BKD Kota Yogyakarta bekerjasama dengan Perguruan Tinggi.

\section{DAFTAR PUSTAKA}

Ambar Teguh Sulistiyani dan Rosidah. 2009. Manajemen Sumber Daya Manusia. Yogyakarta: Graha Ilmu.

Hardiyansyah. 2012. Sistem Administrasi dan Manajemen Sumber Daya Manusia Sektor Publik. Yogyakarta: Gava Media

Keban, Yeremias T. 2008. Enam Dimensi Strategis. Yogyakarta: Gava Media

Lexy J Moleong. 1996. Metodologi Penelitian Kualitatif. Bandung: Rosdakarya

Sugiyono. 2010. Metode Penelitian Kuantitatif Kualitatif dan RND. Bandung: Alfabeta

Suharsimi Arikunto. 1995. Manajemen Penelitian. Jakarta: PT Rineka Cipta

\section{Penelitian}

Lena Satlita dan Yanuardi. 2014. Pelembagaan Reformasi di 
Pemerintah Kota Yogyakarta. FIS UNY: Laporan penelitian

\section{Regulasi}

Peraturan Pemerintah No 10 Tahun 1979

tentang Penilaian Pelaksanaan Pekerjaan

Pegawai Negeri Sipil

Peraturan Walikota Yogyakarta Nomor 21 Tahun 2011 tentang Perubahan Peraturan Walikota Yogyakarta Nomor 23 Tahun 2007 tentang Penilaian Kinerja Pegawai

Peraturan Pemerintah Nomor 46 Tahun 2011 tentang Penilaian Prestasi Kerja PNS.

UU No. 5 Tahun 2014 tentang Aparatur Sipil Negara (ASN) 